\title{
Growth and Characterization of the Virus of Bovine Malignant Catarrhal Fever in East Africa
}

\author{
By W. PLOWRIGHT,* R. F. MACADAM and J. A. ARMSTRONG \\ East African Veterinary Research Organization, Muguga, Kenya; and \\ National Institute for Medical Research, Mill Hill, London, N.W. 7
}

\author{
(Received 3 December 1964)
}

\begin{abstract}
SUMMARY
A strain of bovine malignant catarrhal fever virus (MCF) recovered from the blood of a blue wildebeest was developed by passage in vitro to a stage where it could be propagated serially in primary thyroid cell cultures by inoculation of cell-free fluids. Released virus titres ranged from $10^{3 \cdot 8}$ to $10^{5 \cdot 8}$ $50 \%$ tissue culture infectious doses $/ \mathrm{ml}$. This virus still caused fatal disease when inoculated to cattle, and was neutralized by antibody that appeared in the sera of cattle recovering from experimental infection. The principal cytopathic effects of the virus were the development of DNAcontaining intranuclear inclusions and syncytia; the inclusions became increasingly basophilic as they matured. The cytopathic effects were inhibited in the presence of 5-iodo-2'-deoxyuridine (IUDR), and infectivity of the virus was abolished by treatment with ether or chloroform. Electron microscopy of inoculated cell cultures showed intranuclear, cytoplasmic and extracellular herpes-like virus particles. Suspensions of cell-free virus examined by negative-stain electron microscopy contained some particles of diameter $140 \mathrm{~m} \mu-220 \mathrm{~m} \mu$, comprising an outer envelope and a central body or capsid; others consisted of only a naked capsid about $100 \mathrm{~m} \mu$ in diameter. MCF virus is evidently a member of the herpes group, and has particular affinities to a subgroup which contains the agents of varicella, herpes zoster and the cytomegaloviruses.
\end{abstract}

\section{INTRODUCTION}

Investigations in Kenya have shown that a virus which causes malignant catarrhal fever (MCF) in cattle can be recovered from the blood leucocytes and from splenic tissue of apparently normal specimens of the blue wildebeest Gorgon taurinus taurinus Burchell (Plowright, Ferris \& Scott, 1960; Plowright, 1963). The virus appears to be non-pathogenic for the natural host but produces typical MCF, with a mortality rate exceeding $90 \%$, when inoculated intravenously or subcutaneously into cattle. Cytopathic changes were not detectable in cell cultures prepared from kidney, testis, bone marrow or blood of infected cattle but the virus was cultivated directly in bovine thyroid cell monolayers, causing a regular cytopathic effect with syncytia and intranuclear inclusions. MCF virus behaved at first in a manner similar to the human varicella-zoster agent (Weller, Witton \& Bell, 1958; Taylor-Robinson, 1959) in that no cell-free infectivity was produced during early passages by thyroid cell cultures or by a line of calf kidney cells in

\footnotetext{
* Present address: The Animal Virus Research Institute, Pirbright, Surrey.
} 


\section{W. Plowright, R. F. Macadam and J. A. Armstrong}

which it was serially propagated. After several passages, from 7 to 30 with different isolates, calf kidney cells produced various amounts of free virus which passed through collodion membranes of average pore diameter $430 \mathrm{~m} \mu$ (Plowright et al. 1960). However, it was then not possible to establish a continuous passage series in which cell-free fluid served as the inoculum. The present paper is about more recent experiments which led to the production of a line of MCF virus which was released regularly and at reasonably high titre into the fluid phase of primary calf thyroid cell cultures. This system has been utilized to study the cytopathic changes that accompany virus growth, and for observations about the stability, nucleic acid type and serological identity of MCF virus. Electron microscopy permitted morphological characterization of the virus particles, and revealed details of their intracellular growth.

\section{METHODS}

Virus isolation and passage. A strain (wC 11) of malignant catarrhal fever (MCF) virus was isolated in primary calf thyroid cultures inoculated with leucocytes from the blood of a wildebeest calf captured when less than 1 week old. Cells from a culture in which focal cytopathic changes had become evident were mixed with a suspension of calf kidney cells of the line BK165 and seeded into tubes where monolayers developed; cytopathic foci were visible after 3 days. Further passages in calf kidney cells were made at intervals of between 6 and 10 days, by detaching the cells with $0.02 \%(\mathrm{w} / \mathrm{v})$ EDTA and $0.01 \%(\mathrm{w} / \mathrm{v})$ trypsin and mixing with fresh cell suspensions in the proportion of between $1 / 3$ and $1 / 10$. We shall refer to this passage series as the cell-associated virus (CAV) line. A small amount of cell-free infective virus was first detected in the fluid phase of cultures at the 20th CAV passage, by inoculation of $5 \mathrm{ml}$. of the fluid into freshly established monolayers of calf kidney cells. It was again present in fluids from the 27 th and 43rd passages, but remained at a low value; none was detectable in fluids from the 28th, 29th and 34th passages. Undiluted fluid from the 49 th passage was clarified by centrifugation at $2000 \mathrm{~g}$ for $10 \mathrm{~min}$. and then inoculated in $0.2 \mathrm{ml}$. quantities into tube cultures of primary calf thyroid cells; cytopathic foci were evident from the 3rd day after inoculation. From this point virus appeared regularly in the fluid phase of thyroid cell cultures following inoculation with clarified fluid from the previous passage. This series will be referred to as the released virus (RV) line; it has currently reached its 14th subculture. Fluids harvested on the 5 th day, when the cytopathic effect was usually extensive, contained per ml. between $10^{3 \cdot 8}$ and $10^{5 \cdot 8} 50 \%$ tissue culture infectious doses (TCID 50/ml.) measured by titration in tube cultures of calf thyroid cells. The identity of this agent with earlier wildebeest isolates of MCF virus was indicated by its similar cytopathic effect in vitro, and confirmed by the production of fatal MCF in inoculated cattle after an incubation period of 9-11 weeks.

Virus neutralization tests. Serum was collected from three cattle before and after non-fatal infections with three different wildebeest-derived strains of MCF virus; post-infection samples were also obtained from another three animals which survived. All of these cattle resisted subsequent parenteral challenge of their immunity with virulent MCF virus.

A pooled sample of high-titre serum from cattle infected with infectious bovine rhinotracheitis (IBR) virus was tested for ability to neutralize MCF activity, as were also 12 sera from human (European) adults and three pairs of sera collected 
during the acute and convalescent phases from African children with clinical varicella. All these sera were heated at $56^{\circ}$ for $30 \mathrm{~min}$. before use and immune cattle sera were diluted in tenfold steps in culture maintenance medium. Serum or serum dilutions were mixed with an equal volume of the $R V$ line of virus, estimated to contribute $10^{2 \cdot 0}$ to $10^{2 \cdot 2}$ TCID 50/0.1 ml. The mixtures were shaken and left overnight at $4^{\circ}$, and $0.2 \mathrm{ml}$. quantities of each inoculated on the following day into two to five cultures of primary calf thyroid cells. The final examination for cytopathic effects was made on the 11th or 12th days after inoculation and the titre in quantitative tests was expressed as the reciprocal of the logarithm of the final serum dilution which protected $50 \%$ of the tubes $\left(\log _{10} \mathrm{SN} 50\right)$.

Tissue culture. Calf kidney cells of the established BK 165 line were propagated and maintained as recorded elsewhere (Ferris \& Plowright, 1961). The calf thyroid cultures were prepared as described by Plowright \& Ferris (1961) with a modified lactalbumen hydrolysate+yeast extract growth medium, supplemented with methionine, arginine, glutamine and vitamins as for the basal medium of Eagle (1955). This is similar to the medium designated CSV 6 by Cooper, Wilson \& Burt (1959). For cell growth $10 \%(v / v)$ normal ox serum was added; half this amount was adequate for maintenance. Coverslip monolayers of both cell types, intended for cytological study, were grown and infected with virus of the CAV or RV lines in Petri dishes, and incubated at $37^{\circ}$ in an atmosphere of $5 \%(\mathrm{v} / \mathrm{v})$ carbon dioxide in air.

Metabolic inhibitors. 5-Fluoro-2'-deoxyuridine (FUDR) and 5-iodo-2'-deoxyuridine (IUDR) were dissolved at concentrations from $10^{-7} \mathrm{M}$ to $10^{-3} \mathrm{M}$, in Eagle's basal medium containing $5 \%(\mathrm{v} / \mathrm{v})$ normal ox serum. Tube cultures of calf thyroid cells were rinsed with phosphate buffered saline, and the inhibitor-containing fluids were each added to ten tubes, five of which were immediately inoculated with $10^{3 \cdot 8}$ TCID 50 of a strain of vaccinia virus (Plowright, Witcomb \& Ferris, 1959) and five with $10^{3 \cdot 4}$ TCID 50 of the RV line of MCF virus. Infectivity titrations of the virus inocula were made simultaneously in calf thyroid cells. Microscopical examination of the tubes was made daily for 7 days; the inhibitor-containing media were renewed every second day.

Virus stability. Infective culture fluids containing virus of the RV line were subjected to treatment with $20 \%(\mathrm{v} / \mathrm{v})$ diethyl ether for $18 \mathrm{hr}$ at $4^{\circ}$, following the technique of Andrewes \& Horstman (1949), or $5 \%(\mathrm{v} / \mathrm{v})$ chloroform for $10 \mathrm{~min}$. at $2^{\circ}$ (Feldman \& Wang, 1961). Treated and control samples were then titrated in calf thyroid cell cultures, with five tubes each tenfold dilution.

Cytology. Coverslip monolayers for light microscopy were harvested at daily intervals from 3 to 9 days after virus inoculation, and compared with uninoculated control preparations. Each coverslip was rinsed in $0.85 \%(\mathrm{w} / \mathrm{v}) \mathrm{NaCl}$ to remove excess medium, and transferred for $5 \mathrm{~min}$. into Carnoy or Bouin fixative. Carnoyfixed specimens were stained by the May-Grünwald-Giemsa technique (Jacobson \& Webb, 1952); others, after Bouin or Carnoy fixation, were stained with haematoxylin + eosin. For cytochemical differentiation of nucleic acids (RNA, DNA) a parallel series of Carnoy-fixed monolayers was stained with acridine orange at $\mathrm{pH} 2 \cdot 7$ (Armstrong, 1956); after rinsing in phosphate-buffered saline they were mounted in liquid paraffin and examined with a Zeiss fluorescence microscope, with blueviolet excitation. Feulgen staining for DNA was also done after Carnoy fixation. 


\section{W. Plowright, R. F. Macadam and J. A. Armstrong}

Electron microscopy. Tube cultures of calf thyroid cells were inoculated with cell-free fluid from the 5th passage of the RV line of MCF virus. Each tube received $0.2 \mathrm{ml}$. inoculum, containing about $10^{4 \cdot 0}$ TCID 50 doses of infectious virus. Cytopathic foci were detectable in the unstained monolayers 3 days after inoculation; on the 5 th day all tubes in which at least $75 \%$ of the cell sheet seemed to be affected were harvested, together with uninoculated controls. After removal of culture fluid the cells were fixed in situ for a few minutes with a chilled solution of $1 \%$ $(\mathrm{w} / \mathrm{v}) \mathrm{OsO}_{4}$ buffered to $\mathrm{pH} 7 \cdot 4$ (Palade, 1952) and then carefully dislodged into the fixative by using a rubber pusher. The contents of several tubes were pooled, and fixation continued for about $1 \mathrm{hr}$. After a wash in Hanks's saline the cells were dehydrated with ethanol and embedded in a pre-polymerized 1:4 mixture of methyl$+n$-butyl-methacrylate. Thin sections were collected on grids with carbon-stabilized 'Parlodion' supports. They were stained for $3 \mathrm{hr}$ with a $5 \%(\mathrm{w} / \mathrm{v})$ solution of uranyl acetate in $1 \%(\mathrm{v} / \mathrm{v})$ acetic acid, or by the lead hydroxide method of Dalton \& Zeigel (1960).

For negative-staining of intact virus a fluid harvest from the 10th passage of the RV line, with a titre of $10^{4 \cdot 0} \mathrm{TCID} \mathrm{50} / \mathrm{ml}$., was first clarified by centrifugation at $2000 \mathrm{~g}$ for $10 \mathrm{~min}$. and then concentrated 50 -fold by centrifugation at $30,000 \mathrm{rev} . /$ min. for $90 \mathrm{~min}$. in the no. 30 rotor of a Spinco Model $\mathrm{L}$ centrifuge. The deposit was resuspended in phosphate-buffered saline containing $5 \%(\mathrm{v} / \mathrm{v})$ normal ox serum. A drop was mixed on a carbon-coated specimen grid with a drop of $1 \%(\mathrm{w} / \mathrm{v})$ potassium phosphotungstate $(\mathrm{pH} 6 \cdot 8)$. Most of the fluid was blotted off with filter paper and the specimen was examined without delay. Micrographs were obtained at initial magnifications of up to $\times \mathbf{1 2 , 0 0 0}$ for sections and $\times \mathbf{2 5 , 0 0 0}$ for negativelystained specimens, by the use of Philips EM 75b and EM 200 electron microscopes.

\section{RESULTS}

\section{Neutralization tests}

Bovine sera collected before experimental infection of the animals did not inhibit cytopathogenicity of the released virus (RV) line of malignant catarrhal fever (MCF) virus; but all of the six sera from recovered cattle showed $\log _{10}$ SN 50 titres ranging from $0 \cdot 8$ to $1 \cdot 8$. Infectious bovine rhinotracheitis (IBR) virus antiserum showed no neutralizing action against MCF virus, nor did any of the human sera tested.

\section{Metabolic inhibitors}

Neither 5-iodo-2'-deoxyuridine (IUDR) nor 5-fluoro-2'-deoxyuridine (FUDR) had any visible toxic effect on the uninoculated calf thyroid cells, even at maximum concentration. In the presence of IUDR at $10^{-7} \mathrm{M}$ or $10^{-5} \mathrm{M}$ the cytopathogenicity of vaccinia virus was not affected; but IUDR at a concentration of $10^{-4} \mathrm{M}$ noticeably delayed the appearance of cytopathic effect, and at $10^{-3} \mathrm{M}$ no cytopathic changes were evident during the 7 days of observation. Cytopathic effects due to MCF virus were delayed by IUDR at $10^{-6} \mathrm{M}$ and $10^{-5} \mathrm{M}$, and completely suppressed by $10^{-4} \mathrm{M}$ and above. This suggests that the MCF agent, like vaccinia, is a DNAcontaining virus. In marked contrast, FUDR even at the highest concentrations tested did not obviously inhibit cytopathic changes caused by either vaccinia or MCF virus. Possibly FUDR was readily inactivated by calf thyroid cells, as 
suggested by Hamparian, Hilleman \& Ketler (1963) for primary monkey kidney cells. Alternatively, the explanation may be found in recent studies (e.g. Easterbrook \& Davern, 1963; Stevens \& Groman, 1964) which have shown that inhibition of virus growth by pyrimidine analogues, even when leading to complete suppression of the production of infectious particles, is not necessarily accompanied by suppression of the specific cytopathic effect.

\section{Virus stability}

Ether-treatment of fluid containing $10^{5 \cdot 2}$ TCID 50 of MCF virus $/ \mathrm{ml}$. resulted in total loss of infectivity; chloroform-treatment of fluid containing $10^{4 \cdot 6}$ TCID 50/ml. had the same effect.

\section{Cytopathology}

Calf kidney cell monolayers, fixed and stained at intervals after inoculation with the cell-associated virus (CAV) line of malignant catarrhal fever (MCF) virus, conformed exactly to the original account (Plowright et al. 1960) of focal degeneration in the cell sheet preceded by the development of intranuclear inclusions and large syncytia. In the series of thyroid cell monolayers inoculated with virus of the newly developed released virus (RV) line the gross cytopathic effect was similar, but extended more rapidly through the cell sheet; there was also more variation in the number and size of syncytia, which were sometimes comparatively inconspicuous. Even with the biggest inocula of RV line virus the cellular response remained obviously asynchronous; scattered foci of altered cells were present after 3 days, and the effect had spread to include perhaps $75 \%$ of the monolayer on the 5 th day. After 8 days only a few cells, mostly abnormal, still adhered to the glass. As cells at various stages of infection always co-existed in the cultures, the interpretation in sequential terms must be speculative. In the following description reference to 'early' and 'late' manifestations is based on the degree of departure from normality shown by the cells concerned, and on recognition of a changing pattern of cell types over the period of observation. In Carnoy-fixed cultures stained by the MayGrünwald-Giemsa method the earliest unequivocal change after inoculation was the development of diffuse purplish staining material throughout the nucleus, obscuring the normal pattern of chromatin and nucleoli. These nuclei were mostly larger than normal, suggesting that nuclear swelling may be an early response to infection, and the nuclear membrane frequently showed irregular beading (Pl. 1, figs. 2, 3). After Bouin-fixation and staining with haematoxylin + eosin, the leastaffected cells had nuclei which contained patches of eosinophilic granular material. With either method of fixation and staining, but especially after Bouin-fixation, more advanced nuclear changes were readily seen even at low magnifications: a characteristic 'halo' or retraction space became evident along the inner aspect of the nuclear membrane. The nuclear contents now constituted an inclusion (Pl. 1, fig. 2, 4, 5). Further enlargement of the retraction space was accompanied by further wrinkling and beading of the nuclear membrane, and a gradual shift in the staining reaction of the inclusion towards increased basophilia (Pl. 1, fig. 4). Nucleolar disintegration was also evident, some fragments becoming embedded in the inclusion while others adhered to the nuclear membrane. In some of the cells which showed nuclear alterations, small clusters of basophilic granules were seen 


\section{W. Plowright, R. F. Macadam and J. A. Armstrong}

in juxtanuclear regions of the cytoplasm (Pl. 1, figs. 3, 5); these were not present in uninoculated control cells. In cultures which showed advanced cytopathic effects there were some cells in which the nucleus, besides the changes described, was surrounded by a fringe of radiating eosinophilic projections associated with basophilic granules (Pl. 1, fig. 6). With the increase of nuclear abnormality there was a tendency for the cells to round-up and become detached from the monolayer; fragmentation of the nucleus into basophilic debris and the presence of branching processes radiating from the cell periphery were signs of impending detachment.

An interesting feature of multinucleate cells in these cultures, whether small ones with only two or three nuclei or more extensive syncytial masses, was the coexistence of nuclei showing very different degrees of alteration. Presumably this is attributable to fusion (or recruitment) of neighbouring cells, of which some were normal and others in various stages of infection. Cytoplasmic vacuolation was prominent in some syncytia.

Staining for nucleic acids. With acridine orange, normal calf kidney and thyroid cells showed the usual flame-red fluorescence of cytoplasmic RNA-containing material. Nuclear chromatin gave the greenish yellow emission characteristic of DNA, and multiple red nucleoli were always in close relation to well-developed patches of nucleolus-associated chromatin. After inoculation, cells of otherwise normal appearance became conspicuous because of peculiarly diffuse DNA-containing material which accumulated in the nucleus (Pl. 1, fig. 7). In the later stages a strong fluorescence for DNA was given by the fully developed intranuclear inclusions (Pl. 1, fig. 8); small red-fluorescing globules occurred inside the inclusions and on the wrinkled nuclear membrane, and are assumed to represent nucleolar remnants. The peripheral 'halo' or retraction space was not fluorescent after acridine orange staining. Feulgen-stained monolayers likewise indicated the presence of a substantial amount of DNA in the intranuclear inclusions. With the acridine orange and the Feulgen methods where juxtanuclear cytoplasmic inclusions occurred they too gave positive reactions for DNA.

\section{Electron microscopy}

No unusual features were noted in sections of uninoculated control cell cultures. The cells were of normal appearance and contained no recognizable virus particles. In marked contrast, cells sectioned 5 days after inoculation with the RV line of MCF virus were morphologically abnormal and virus-like particles were identifiable in intimate relation to the cells.

Nuclear changes. Margination of chromatin and an absence of recognizable nucleoli were the most obvious signs of nuclear involvement. The interior of such nuclei was less dense than in normal cells, and closer inspection showed that normal nuclear fine structure had been replaced by a heterogeneous matrix with particulate and fibrillar components (Pl. 2, fig. 9). Rounded profiles, with a regularity of size and form that at once suggested virus particles, were scattered in seemingly random fashion throughout the nucleus (Pl. 2, fig. 10). Each virus-like particle was about $90 \mathrm{~m} \mu$ in diameter and consisted of an internal dense body, or nucleoid, separated by a clear zone from a single dense peripheral ring. The nucleoid measured about $40 \mathrm{~m} \mu$; it was sometimes uniformly dense, but more often had a pale centre giving an annular profile on section. Aggregates of virus-like particles tended to occur 
near to the nuclear envelope; orientation of the particles in linear array was noticed occasionally in the larger aggregates, suggesting the onset of viral crystallization in situ (Pl. 3, fig. 11). Interspersed with the intranuclear virus particles was a meshwork of coarse irregular filaments, the outlines of which often suggested an incomplete or precursor form of virus particle, but convincing evidence for such an interpretation is lacking.

Another interesting feature was present in a small proportion of the affected nuclei. This was a system of fine ramifying tubular formations, limited to the periphery of the intranuclear matrix. It was possible in places to observe continuity between the tubules and the inner layer of the nuclear envelope, from which they seemed to originate as multiple invaginations. Some were dilated, giving rise to intranuclear vesicles continuous with the space between the two layers of the nuclear envelope. Virus-like particles occurred around and within such vesicles, those on the outside were of the typical $90 \mathrm{~m} \mu$ single-ringed variety; but those inside the vesicles were larger, each having a duplicated peripheral ring and a total diameter of about $130 \mathrm{~m} \mu$ (Pl. 3, fig. 12). In effect, such particles can be regarded as extranuclear.

Small ring-like structures with a diameter of about $20 \mathrm{~m} \mu$ occurred in profusion in certain cell nuclei (Pl. 3, fig. 13), typically in areas devoid of the well-defined $90 \mathrm{~m} \mu$ virus particles. They had no morphological resemblance to previously recognized viruses; since they were generally most numerous in cells at an advanced stage of infection it is possible they represent some by-product of intranuclear virus replication.

Cytoplasmic changes. The response of the cytoplasm in thyroid cells inoculated with MCF virus was invariably less dramatic than that of the corresponding nuclei. However, a characteristic feature, never seen in uninoculated control cells, was aggregation of the mitochondria; it occurred chiefly around the nucleus and near the Golgi complex (Pl. 4, fig. 15).

Virus-like particles, clearly comparable with those present in the nucleus, were demonstrable in the cytoplasm in relatively small numbers, but there was no obvious tendency for them to accumulate in the cytoplasm. Those seen most commonly were of the larger double-ringed type, measuring $130 \mathrm{~m} \mu$ in diameter; they were situated, singly or in small groups, in closed cytoplasmic vesicles (Pl. 5, figs. 16, 17). They did not occur free in the cytoplasm, nor within the confines of the endoplasmic reticulum. The virus-containing vesicles were widely distributed between the nucleus and the cell surface.

Apart from the intravesicular particles, a small proportion of cells also contained a prominent cytoplasmic body consisting of numerous virus particles embedded in a dense granular matrix. The body was juxtanuclear in position, closely related to the Golgi complex and to the mitochondrial aggregates already mentioned (Pl. 4, fig. 15). On section, each of these bodies measured up to several microns across but was irregular in shape; no membrane which separated it from surrounding cytoplasm was discernible. The contained virus particles were mainly of the single-ringed $90 \mathrm{~m} \mu$ type, but larger ones with double-rings were occasionally present. For the most part, it was not feasible to differentiate the virus particles from the granular material in which they were embedded, since many of them seemed to be morphologically incomplete. Often a central nucleoid was entirely lacking and in other cases it was represented only by a short dense filament reaching out of the particle itself 
into the surrounding matrix or adjacent cytoplasm. In short, the dense bodies were composed mainly of fragmentary virus particles; their frequency and location suggested probable identity with the juxtanuclear basophilic masses identified by light microscopy.

Extracellular virus. Numerous virus particles occurred on the surface of cells which showed the nuclear and cytoplasmic changes described. Individual particles were usually adherent to the outer aspect of folded portions of the cell membrane, while large clusters of apparently free virus particles were located in intercellular clefts throughout the cell sheet (Pl. 3, fig. 14). All extracellular particles were of the double-ringed type, with a diameter about $130 \mathrm{~m} \mu$.

Negative-staining electron microscopy. These preparations contained a substantial number of particles with undoubted viral characteristics. They were of two distinct morphological types, enveloped and naked; the two types occurred in clusters with about equal frequency but were rarely intermingled. Enveloped particles (Pl. 5, fig. 18) possessed a loose external membrane of irregular outline, enclosing a central body (or capsid) having a well-defined and regular profile. Overall size of enveloped particles ranged from 140 to $220 \mathrm{~m} \mu$, while the central body measured about $100 \mathrm{~m} \mu$. Naked particles (Pl. 5, fig. 19) appeared circular or, quite often, hexagonal in outline; they measured $100 \mathrm{~m} \mu$ across and closely resembled the central bodies of enveloped particles. At high magnification they were seen to be coated with regular subunits (capsomeres) of a hollow and elongated character. Each subunit had a diameter of about $9.5 \mathrm{~m} \mu$, and the length of those viewed in profile round the particle periphery was about $12.5 \mathrm{~m} \mu$. Similar but less well revealed subunits were discernible on the central body of many of the enveloped particles.

\section{DISCUSSION}

The strain of virus used in this study is typical of those that have been isolated from wildebeest or cattle naturally infected with malignant catarrhal fever (MCF) in East Africa. The released virus (RV) line of this isolate was still capable of producing fatal disease on parenteral inoculation into cattle and was neutralized by antibody which appeared in the serum of other cattle which had recovered from experimental MCF. It was not neutralized by antisera against infectious bovine rhinotracheitis virus or by adult human sera, some of which presumably contained antibodies to herpes simplex, varicella and herpes zoster viruses. The cytopathic effect of the RV line of MCF virus was essentially similar to that produced by primary MCF isolates in calf thyroid cells, and the virus-like particles now demonstrated in intimate relation with the altered cells, and in culture fluids, represent without doubt the causal agent of malignant catarrhal fever in East Africa.

The original report on wildebeest isolates of malignant catarrhal fever (MCF) virus (Plowright et al. 1960) called attention to some herpes-like properties, notably in regard to their epizoötiological behaviour and cytopathic effects in monolayer cultures. Subsequent experience with this virus in the laboratory has confirmed the earlier impressions: in addition to the cytopathological details, affinity with the herpes group is indicated by the demonstration of ether and chloroform sensitivity, and by the suppression of cytopathic changes in the presence of 5-iodo-2'-deoxy- 
uridine which selectively inhibits DNA synthesis. Owing to the exclusive production of cell-associated virus during early culture passages, the original MCF virus isolates were likened to the subgroup of herpes viruses which includes the varicella and zoster agents. It has recently been suggested (Melnick et al. 1964) that cytomegaloviruses should also be included in this category, although their ability to produce cell-free infectious virus is greater than with the other agents mentioned (Smith, 1959). Varicella produces much cell-free infectivity in the tissues of man (Weller et al. 1958; Taylor-Robinson, 1959) but none was demonstrable in tissue extracts or sonically-disrupted cells from MCF virus-infected cattle (Plowright, 1963). Caunt (1963) found that a considerable quantity of stable infectious virus may be liberated ultrasonically from the cells of human thyroid cultures infected with varicella virus. The development of the RV line of MCF virus is a comparable achievement showing that failure to produce appreciable amounts of free infectivity in vitro is not an absolute and immutable characteristic of this subgroup. A morphological basis for the absence of stable free infectious virus has not been established for any of the agents discussed, but it might well be dependent on a failure to produce or release particles having an outer envelope; the latter, it has been suggested, may be required for infectivity in the case of herpes simplex (Smith, 1964).

The finding of basophilic Feulgen-positive granules in the cytoplasm of cells infected with MCF virus recalls similar observations on cells infected with cytomegaloviruses, either in vivo or in vitro (Smith, 1964; McAllister, Straw, Filber \& Goodheart, 1963). Similarly, the increasing basophilia of the intranuclear inclusions in MCF virus-infected cells may indicate a closer resemblance to the cytomegaloviruses than to the classical herpes viruses, which produce mature inclusions often regarded as necessarily eosinophilic (Andrewes et al. 1961; Pereira, 1962). Nevertheless, in certain circumstances esosinophilic type A inclusions do not always develop in HeLa cells infected with herpes simplex virus, probably because the nuclei contain an excess of DNA which persists into the late stages of infection (Newton \& Stoker, 1958). Felgenhauer \& Stammler (1962) also failed to demonstrate Feulgen-negative inclusions in mouse fibroblast cultures infected with the same virus and fixed briefly in Carnoy's fluid. In addition, 'amphophilic' staining properties are on record for the nuclear inclusions of infectious bovine rhinotracheitis virus, an established bovine member of the herpes group (Cheatham \& Crandell, 1957). It is perhaps appropriate to question whether tinctorial conformity with the original concept of type A nuclear inclusions (Cowdry, 1934) should continue to be regarded as significant for purposes of virus classification; cytological, biophysical and chemical criteria of a more basic and reproducible nature are now available to the taxonomist (Andrewes et al. 1963).

In respect of size, morphology, and relationship to the host cell the malignant catarrhal fever particles bear a strong resemblance to elementary particles of the herpes group. Details of herpes virus morphology and development have been described, amongst others, for herpes simplex virus (Morgan, Rose, Holden \& Jones, 1959), simian B virus (Reissig \& Melnick, 1955), avian infectious laryngotracheitis virus (Watrach et al. 1959), infectious bovine rhinotracheitis virus (Armstrong, Pereira \& Andrewes, 1961) and equine abortion virus (Arhelger, Darlington \& Randall, 1963). In common with these reports, electron microscopy of MCF virusinoculated cells points to the nucleus as the primary site of viral replication; 
single-ringed particles measuring $90 \mathrm{~m} \mu$ seem to be assembled there in a manner indistinguishable from that of acknowledged herpes viruses. A second ring is acquired by each particle on leaving the nucleus, and evidently consists of a membranous investment from the inner layer of the bilaminar nuclear envelope. The factors which initiate and control the extrusion of particles from the nucleus remain obscure. The occasional presence of vesicular ingrowths from the nuclear envelope, containing double-ringed virus particles, was noted earlier for herpes simplex virus (Falke, Siegert \& Vogell, 1959) and for a human cytomegalovirus (Stern \& Friedmann, 1960).

As there were no recognizable cytoplasmic foci of MCF virus replication, it is likely that all of the double-ringed particles observed in cytoplasmic vesicles were being transported at the moment of fixation, either from the nucleus towards the cell surface or in the reverse direction. Recent work with herpes simplex virus, in which electron-opaque tracers were mixed with the virus inoculum, showed clearly that in cell cultures the virus did indeed enter cells as a consequence of phagocytosis and became incorporated into cytoplasmic vesicles (Holmes \& Watson, 1963; Epstein, Hummeler \& Berkaloff, 1964). The subsequent fate of ingested particles, in the 'eclipse phase', preceding appearance of newly synthesized virus particles, has not yet been clearly defined in morphological terms; but it is commonly supposed that enzymic digestion of the engulfed particles explains their disappearance and accounts for the uncoating of infectious viral nucleic acid. In the present experiments it was not possible to distinguish between 'ingoing' and 'outgoing' cytoplasmic MCF virus particles, but there is no reason to doubt that both forms were present in many of the cells examined.

It is tentatively proposed that the dense juxtanuclear mass of fragmentary MCF virus particles, observed in a proportion of the cells, may have a bearing upon the fate of phagocytosed virus. It is only to be expected, in the later stages of infection that some cells in the cultures would be ingesting unusually large amounts of virus released into the medium from nearby infected cells; it is now suggested that this was followed by localization of a mass of partially digested virus material in the vicinity of the Golgi complex, where there were signs of viral nucleoids being released into the surrounding cytoplasm. Similar viral aggregates seem so far not to have been noticed in studies on the typical herpes viruses; but closely comparable dense bodies were met with in a recent investigation of the liver in mice, following intraperitoneal inoculation with a murine cytomegalovirus (Ruebner et al. 1964). These workers considered the dense masses to be sites of viral destruction, possibly in the lysosomal category; the hypothesis advanced here for MCF virus accords well with their interpretation.

In correlating information on virus particles based on thin sections with that obtained by negative-staining electron microscopy, some allowance for technical distortion is necessary. Shrinkage tends to occur during dehydration and embedding before cutting sections, while collapse and spreading of unsupported membranes and other non-rigid components can be expected in specimens allowed to dry in phosphotungstate. In the circumstances, there was reasonable correspondence in size and structural detail between the single- and double-ringed particles seen in thin sections, and the naked and enveloped forms revealed by negative staining; they may be regarded as identical. The measured size of the larger enveloped particles 
coincides with that obtainable by applying the factor of Black (1958) to our most recent data on the passage of MCF virus through graded collodion membranes: all infectivity was held up by membranes of $275 \mathrm{~m} \mu$ average pore diameter whilst others of $300 \mathrm{~m} \mu$ allowed virus to pass. From this it is calculated that the minimum diameter of the infectious MCF particles was approximately $180 \mathrm{~m} \mu$. The exact number of hollow elongated subunits comprising the capsid of MCF virus has not yet been determined. Nevertheless, the present observations leave little doubt that the viral architecture will prove to be indistinguishable from the icosahedral pattern, with 162 subunits, that has been established for herpes simplex (Wildy, Russell \& Horne, 1960), cytomegalovirus (Smith \& Rasmussen, 1963), varicella virus (Almeida, Howatson \& Williams, 1962) and the virus of avian infectious laryngotracheitis (Watrach, Hanson \& Watrach, 1963).

The authors are grateful to Dr R. C. Valentine for co-operation in the negativestaining electron microscopy, and to Mr R. F. Staple, A.I.M.L.T., for photographic assistance. We are also indebted to Smith, Kline and French Laboratories, Ltd., and to F. Hoffman-La Roche and Co. Ltd., Basel, who donated respectively the 5-iodo-2'-deoxyuridine and 5-fluoro-2'-deoxyuridine used in this investigation.

\section{REFERENCES}

Almeida, J. D., Howatson, A. F. \& Williams, M. G. (1962). Morphology of varicella (chickenpox) virus. Virology, 16, 353.

Andrewes, C. H., Burnet, F. M., Enders, J. F., Gard, S., Hirst, G. K., Kaplan, M. M. \& ZHDANOv, V. M. (1961). Taxonomy of viruses infecting vertebrates; present knowledge and ignorance. Virology, 15, 52.

Andrewes, C. H., Gard, S., Hammond, W. M., McWhorter, F. P. \& Zhdanov, V. M. (1963). Recommendations on virus nomenclature. Virology, 21, 516.

Andrewes, C. H. \& Horstman, D. M. (1949). The susceptibility of viruses to ethyl ether. J. gen. Microbiol. 3, 290.

Arhelger, R. B., Darlington, R. W. \& Randall, C. C. (1963). An electron microscopic study of equine abortion virus infection in hamster liver. Amer. J. Path. 42, 703.

Armstrong, J. A. (1956). Histochemical differentiation of nucleic acids by means of induced fluorescence. Exp. Cell Res. 11, 640.

Armstrong, J. A., Pereira, H. G. \& Andrewes, C. H. (1961). Observations on the virus of infectious bovine rhinotracheitis and its affinity with the Herpes virus group. Virology, 14, 276.

BLACK, F. L. (1958). Relationship between virus particle size and filterability through gradocol membranes. Virology, 5, 391.

CAUNT, A. E. (1963). Growth of varicella-zoster virus in human thyroid tissue cultures. Lancet, ii, 982.

Cheatham, W. J. \& Crandeli, R. A. (1957). Occurrence of intranuclear inclusions in tissue cultures infected with virus of infectious bovine rhinotracheitis. Proc. Soc. exp. Biol., N.Y. 96, 536.

Cooper, P. D., Wilson, J. N. \& Burt, A. M. (1959). The bulk growth of animal cells in continuous suspension culture. J. gen. Microbiol. 21, 702.

CowDry, E. V. (1934). The problem of intranuclear inclusions in virus diseases. Arch. Path. 18, 527.

Dalton, A. J. \& Zeigel, R. F. (1960). A simplified method of staining thin sections of biological material with lead hydroxide for electron miscroscopy. J.biophys. biochem. Cytol. 7, 409. 


\section{W. Plowright, R. F. Macadam and J. A. Armstrong}

EAGLe, H. (1955). The minimum vitamin requirements of the $L$ and HeLa cells in tissue culture, the production of specific vitamin deficiencies and their cure. $J . \exp . M e d$. $102,595$.

Easterbrook, K. E. \& Davern, C. I. (1963). The effect of 5-bromodeoxyuridine on the multiplication of vaccinia virus. Virology, 19, 509.

Epstein, M. A., Hummeler, K. \& Berkaloff, A. (1964). 'The entry and distribution of herpes virus and colloidal gold in HeLa cells after contact in suspension. J. exp. Med. 119, 291.

Falke, D., Siegert, R. \& Vogell, W. (1959). Elektronmikroskopische Befunde zur Frage der Doppelmembranbildung des Herpes-simplex-Virus, Arch. ges. Virusforsch. 9, 484.

Feldman, H. A. \& Wang, S. S. (1961). Sensitivity of various viruses to chloroform. Proc. Soc. exp. Biol. N.Y. 106, 736.

Felgenhauer, K. \& Stammler, A. (1962). Histochemically detected changes in cell cultures infected with herpes simplex virus. Arch. ges. Virusforsch. 12, 223.

Ferris, R. D. \& Plowright, W. (1961). The serial cultivation of calf kidney cells for use in virus research. Res. vet. Sci. $2,387$.

Hamparian, V. V., Hilleman, M. R. \& Ketler, A. (1963). Contributions to characterization and classification of animal viruses. Proc. Soc. exp. Biol., N.Y. 112, 1040.

Holmes, I. H. \& Watson, D. H. (1963). An electron microscope study of the attachment and penetration of herpes virus in BHK 21 cells. Virology, 21, 112.

$J_{\text {ACOBSON, }}$ W. \& WeBB, M. (1952). The two types of nucleoproteins during mitosis. Exp. Cell Res. 3, 163.

Melnick, J. L., Midulla, M., Wimberleey, I., Barrera-Oro, J. G. \& Levy, B. M. (1964). A new member of the Herpes virus group isolated from South American marmosets. J. Immunol. 92, 596.

McAllister, R. M., Straw, R. M., Filbert, J. E. \& Goodheart, C. R. (1963). Human cytomegalovirus. Cytochemical observations of intracellular lesion development correlated with viral synthesis and release. Virology, 19, 521.

Morgan, C., Rose, H. M., Holden, M. \& Jones, E. P. (1959). Electron microscopic observations on the development of herpes simplex virus. J. exp. Med. 110, 643.

Palade, G. E. (1952). A study of fixation for electron microscopy. J. exp. Med. 95, 285.

Newton, A. \& Stoker, M. P. G. (1958). Changes in nucleic acid content of HeLa cells infected with herpes virus. Virology, $5,549$.

Pereira, H. G. (1962). The cytopathic effect of animal viruses. Adv. Virus Res. 8, 245.

Plowright, W. (1963). Studies on the virus of malignant catarrhal fever in Africa. Proc. 17th World vet. Congr., Hannover, 1, 276.

Plowright, W. \& Ferris, R. D. (1961). The preparation of bovine thyroid monolayers for use in virological investigations. Res. vet. Sci. 2,149 ,

Plowright, W., Ferris, R. D. \& Scotr, G. R. (1960). Blue wildebeest and the aetiological agent of bovine malignant catarrhal fever. Nature, Lond. 188, 1167.

Plowright, W., Wutcomb, M. A. \& Ferris, R. D. (1959). Studies with a strain of contagious pustular dermatitis virus in tissue culture. Arch. ges. Virusforsch. 9, 214.

Reissig, M. \& Mexnick, J. (1955). The cellular changes produced in tissue cultures by herpes $\mathrm{B}$ virus correlated with the concurrent multiplication of the virus. J. exp. Med. 101, 341.

Ruebner, B. H., Miyai, K., Slusser, R. J., Wedemeyer, P. \& Medearis, D. N. (1964). Mouse cytomegalovirus infection. An electron microscopic study of hepatic parenchymal cells. Amer. J. Path. 44, 799.

SMIrH, K. O. (1964). Relationship between the envelope and the infectivity of herpes simplex virus. Proc. Soc. exp. Biol., N.Y. 115, 814.

Smith, K. O. \& Rasmussen, L. (1963). Morphology of cytomegalovirus (salivary gland virus). J. Bact. 85, 1319.

Sмrтн, M. G. (1959). The salivary gland viruses of man and animals (cytomegalic inclusion disease). Prog. med. Virol. 2, 171.

Stern, H. \& FrienmanN, I. (1960). Intranuclear formation of cytomegalic inclusion disease virus. Nature, Lond. 188, 768. 
StEvens, J. G. \& Groman, N. B. (1964). Infectious bovine rhinotracheitis virus replication cytopathology and plaque formation in the presence and absence of nucleic acid analogues. J. Bact. 87, 446.

Taylor-Robinson, D. (1959). Chicken pox and herpes zoster. III. Tissue culture studies. Brit. J. exp. Path. 40, 521.

Watrach, A. M., Hanson, L. E. \& Watrach, M. A. (1963). The structure of infectious laryngotracheitis virus. Virology, 21, 601.

Watrach, A. M., Vatter, A. E., Hanson, L. E., Watrach, M. A. \& Rhondes, H. E. (1959). Electron microscopic studies of the virus of avian infectious laryngotracheitis. Amer. J. vet. Res. $20,537$.

Weller, T. H., Witton, H. M. \& Bell, E. J. (1958). The etiologic agents of varicella and herpes zoster. J. exp. Med. 108, 843.

Wildy, P., Russell, W. C. \& HoRne, R. W. (1960). The morphology of herpes virus. Virology, 12, 204.

\section{EXPLANATION OF PLATES}

Plate 1

Figs. 1-6 are photomicrographs of 9-day monolayers of primary calf thyroid cells; all except fig. 4 were Carnoy-fixed and stained by the May-Grünwald-Giemsa method.

Fig. 1. Uninoculated culture $(\times 1000)$.

Fig. 2. Culture infected 4 days previously with the released virus (RV) line of malignant catarrhal fever (MCF) virus, showing nuclear enlargement and masking of the normal chromatin pattern; two nuclei contain early inclusions surrounded by a narrow halo and show beading of the nuclear membrane $(\times 1000)$.

Fig. 3. Cells in a 4-day-infected culture, in which diffuse intranuclear staining largely masks the chromatin network: note also slight beading of the nuclear membrane, early halo-formation around the nuclear contents, and the presence of basophilic granules in the juxtanuclear cytoplasm $(\times 1000)$.

Fig. 4. Well-formed basophilic intranuclear inclusions, each surrounded by a wide clear zone or halo. Haematoxylin-eosin, after Bouin fixation $(\times 1250)$.

Fig. 5. Infected cell with an intranuclear inclusion, showing also a prominent juxtanuclear cluster of basophilic granules $(\times 1500)$.

Fig. 6. A cell with diffuse intranuclear staining and beading of the nuclear membrane, also showing a perinuclear fringe of eosinophilic processes accompanied by small basophilic granules $(\times 1500)$.

Figs. 7 and 8 are fluorescence photomicrographs of BK165 cell cultures, infected with the cellassociated virus (CAV) line of MCF virus and stained with acridine orange. Fig. 7 shows a syncytium with seven nuclei, two of which (right of centre) are of normal appearance. Others (arrows) are filled with diffuse material giving the yellow-green fluorescence characteristic of DNA. The syncytium in fig. 8 contains two nuclei (arrow) with well-developed inclusions emitting intense yellow-green fluorescence. Prints made from original colour transparencies $(\times 625)$.

\section{Plate 2}

Electron micrographs of calf thyroid cells.

Fig. 9. Section illustrating the abnormal nuclear morphology found in many cells 5 days after inoculation with malignant catarrhal fever virus. Notice margination of the chromatin, and a heterogeneous intranuclear matrix $(\times 32,000)$.

Fig. 10. Nuclear fine structure observed at higher magnification, and showing a collection of $90 \mathrm{~m} \mu$ virus-like particles: the particles consist of an outer dense ring and a central nucleoid $(\times 50,000)$.

\section{Plate 3}

Electron micrographs of calf thyroid cells.

Fig. 11. Relatively large aggregate of typical intranuclear virus-like particles: linear orientation of particles on the right in this field suggests incipient virus crystallization $(\times 39,000)$.

Fig. 12. Virus particles of the double-ringed type (approximate diameter $130 \mathrm{~m} \mu$ ) lying in an intranuclear vesicle the limiting membrane of which is indicated by arrows $(\times 80,000)$. 


\section{W. Plowright, R. F. Macadam and J. A. Armstrong}

Fig. 13. Intranuclear detail in a cell that showed obvious signs of degeneration 5 days after inoculation. Small $(20 \mathrm{~m} \mu)$ ring-like bodies of unknown significance are numerous; for comparison, a typical single-ringed virus particle is seen at the top right $(\times \mathbf{3 2 , 0 0 0})$.

Fig. 14. Clusters of extracellular virus particles, situated in spaces between neighbouring cells of the monolayer $(\times 32,000)$.

\section{Plate 4}

Fig. 15. Section of thyroid cell in an inoculated culture, showing a prominent juxtanuclear dense mass in the cytoplasm; it appears to be composed mainly of fragmentary virus particles. Note the occurrence of nearby mitochondrial aggregates (M). $\mathbf{N}=$ Nucleus. Electron micrograph $(\times 40,000)$.

\section{Plate 5}

\section{Electron micrographs}

Fig. 16. Section through neighbouring cells in an inoculated culture showing typical, $130 \mathrm{~m} \mu$ double-ringed virus particles enclosed in cytoplasmic vesicles (arrows). That on the left appears to be fragmenting, and may be an 'ingoing' particle within a phagocytic vesicle derived from the cell membrane. Two particles at the upper right are intact, and closely invested by the vesicle membrane; these may represent 'outgoing' virus particles $(\times 50,000)$.

Fig. 17. Intravesicular cytoplasmic virus particle at high magnification. In the case of 'outgoing' particles, i.e. proceeding from their origin in the nucleus towards the cell surface, the enclosing vesicle is presumed to originate as an evagination from the outer layer of the nuclear envelope $(\times 100,000)$.

Figs. 18, 19. Phosphotungstate negative-stain preparations of tissue culture fluid containing cellfree malignant catarrhal fever virus. A typical enveloped particle is seen in fig. 18 and a naked one in fig. 19. On the latter can be seen hollow surface subunits (capsomeres) the elongated nature of which is revealed by those viewed in profile at the edge of the particle $(\times 200,000)$. 
Journal of General Microbiology, Vol. 39, No. 2

Plate 1
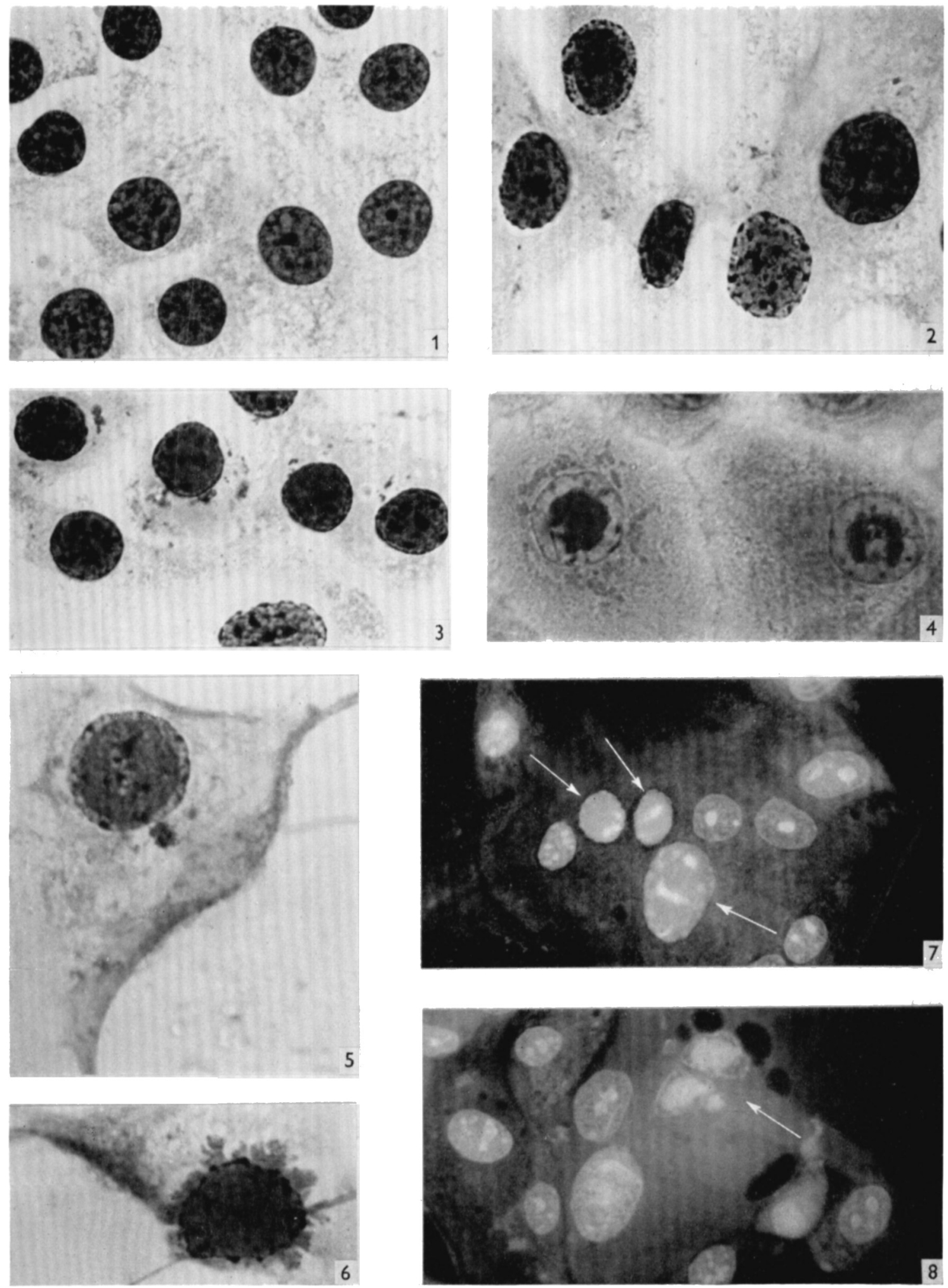

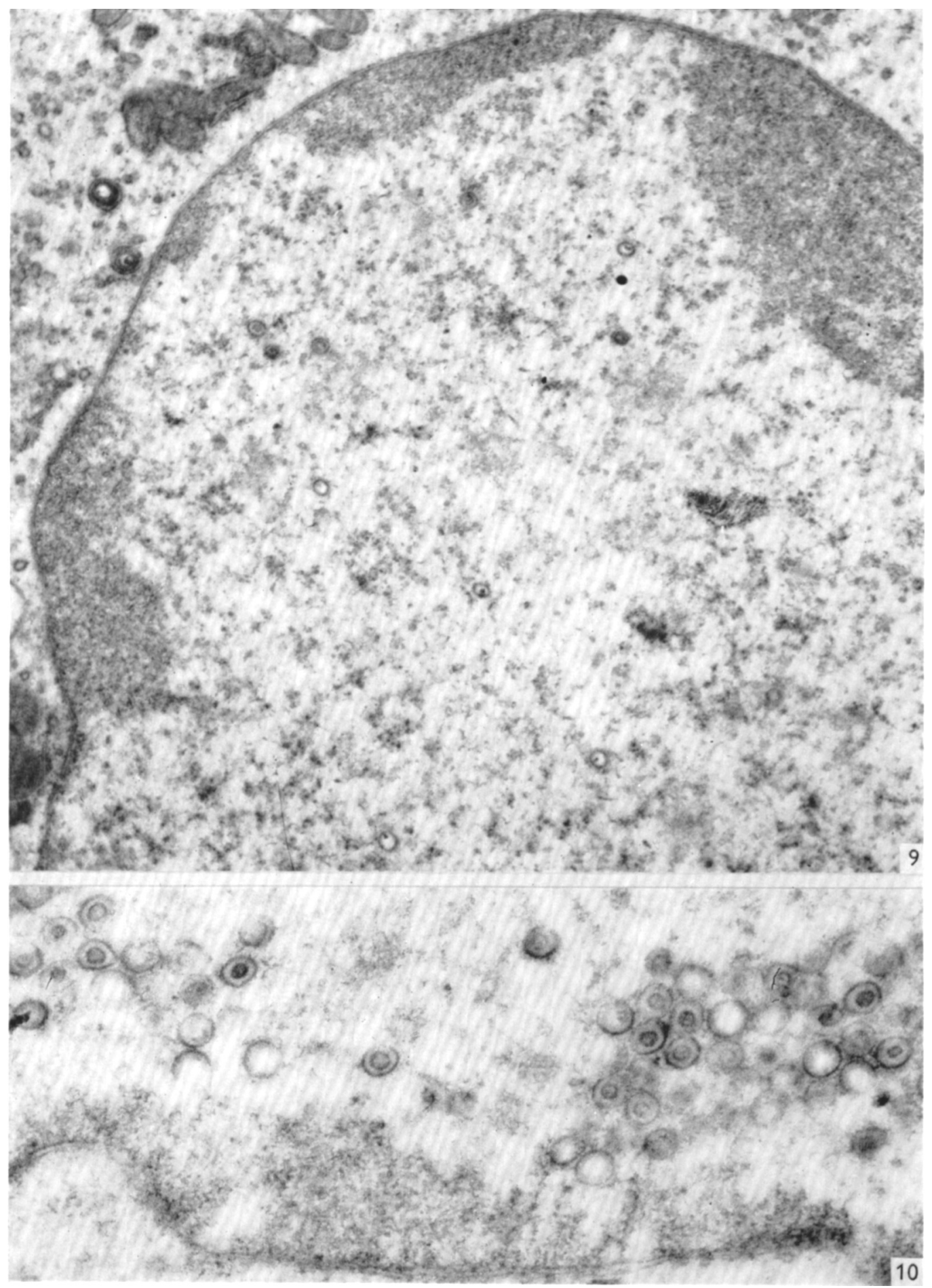

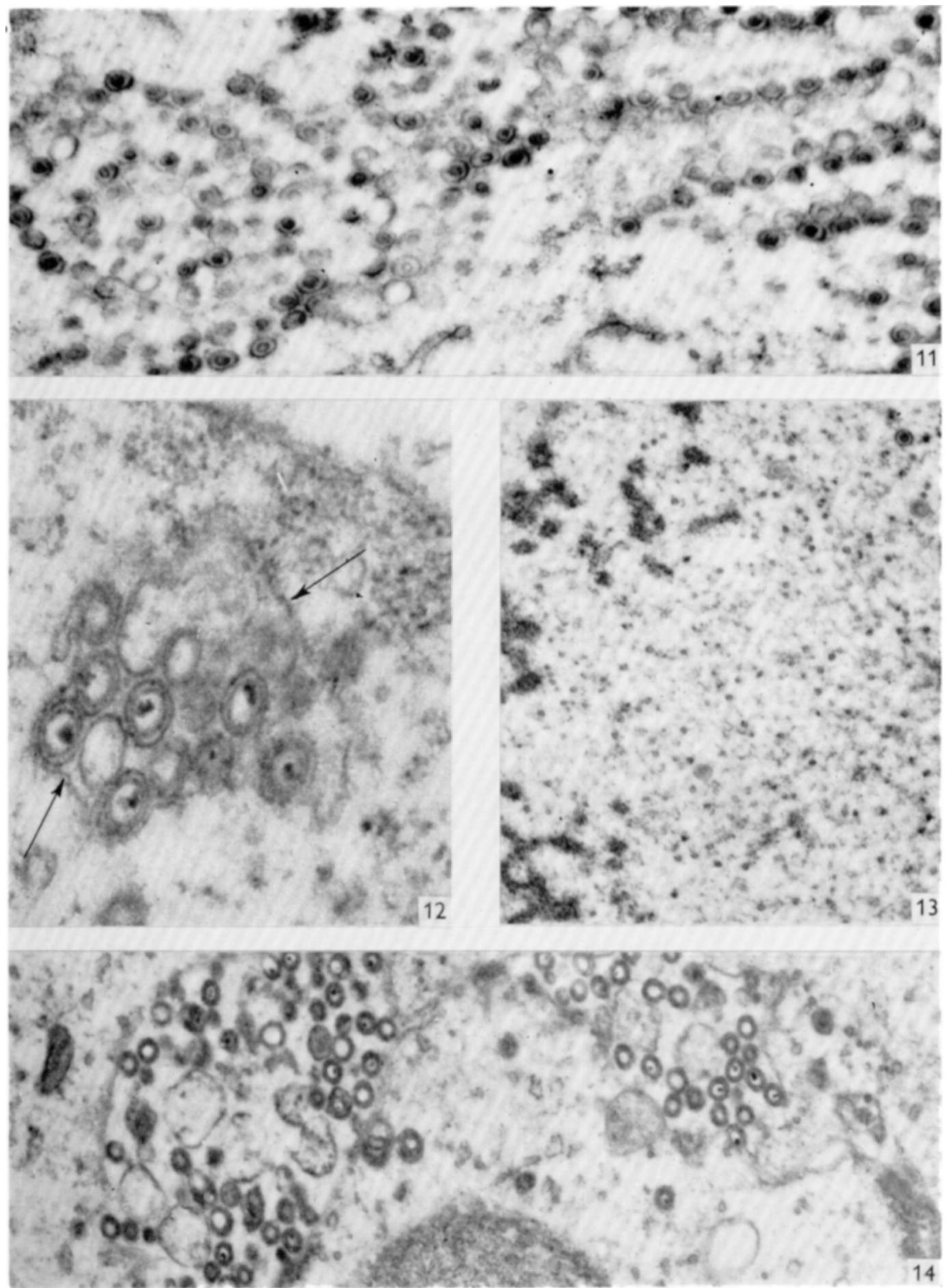

W. PLOWRIGH'T, R. F MACADAM AND J. A. ARMSTRONG 


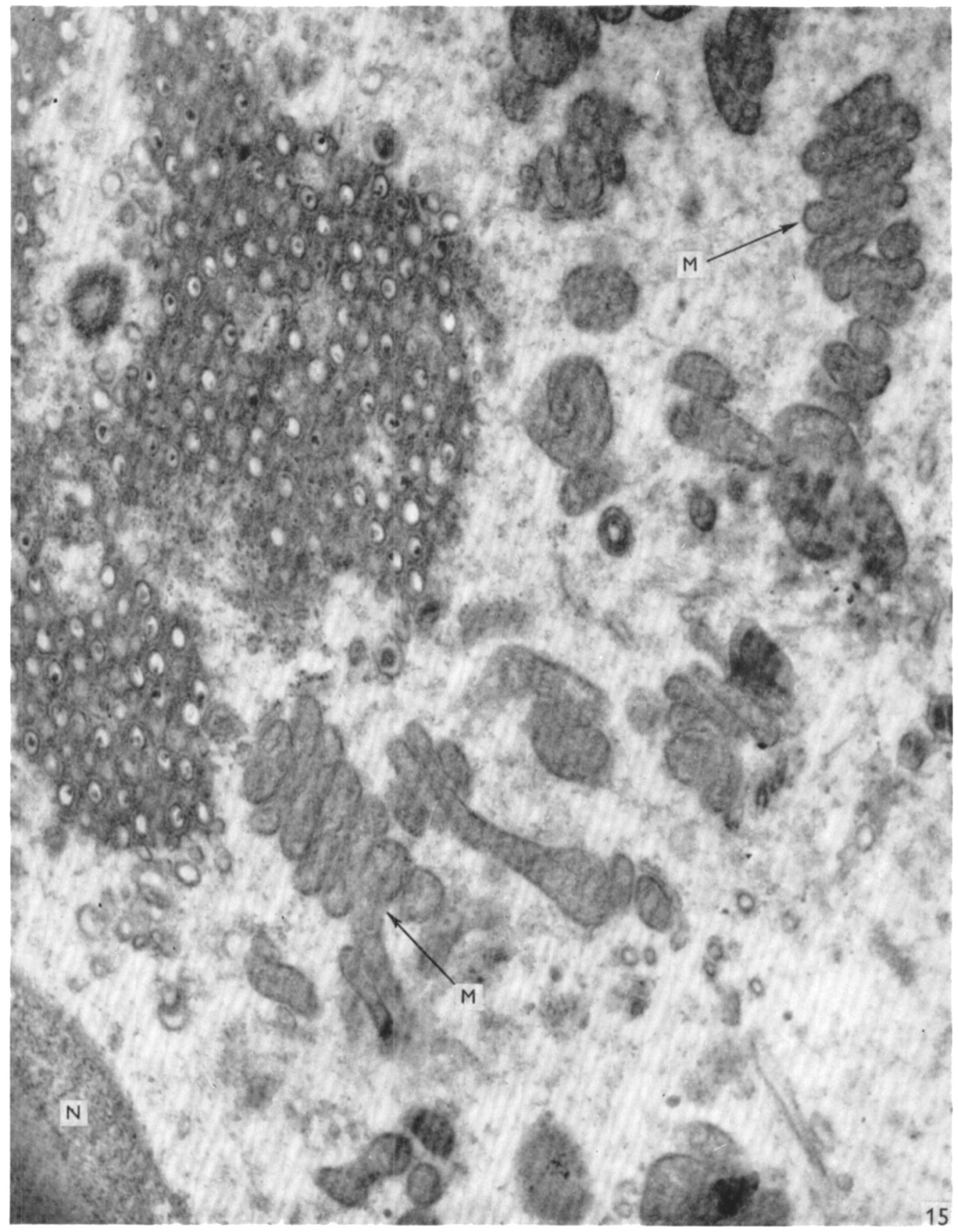

W. PLOWRIGH'T, R. F. MACAI) AM AND .J. A. ARMSTRONG 

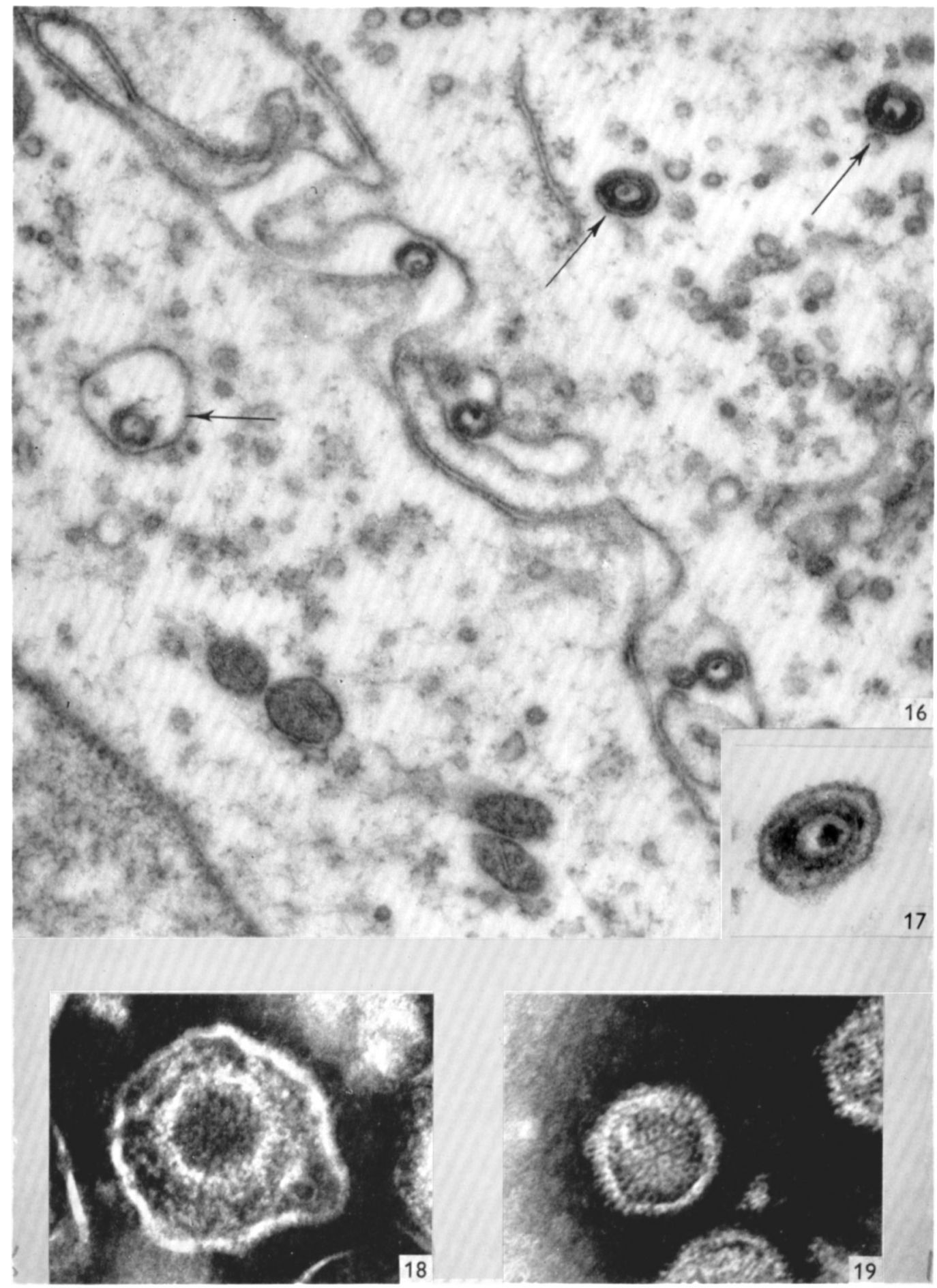

W. PLOWRIGHT, R. F. MACADAM AND J. A. ARMSTRONG 